\title{
HUNGARIAN LANGUAGE TECHNICAL TERMINOLOGY FROM 1920 UNTIL TODAY
}

\author{
Irén ZABÓNÉ VARGA
}

Óbuda University, Donát Bánki Faculty of Mechanical and Safety Engineering, Institute of Materials and Manufacturing Sciences, Budapest, Hungary, zabone.iren@bgk.uni-obuda.hu

\begin{abstract}
This study is the last one of a three-part series reviewing the history of Hungarian language technical terminology. In this article, we strive to present all the factors that have influenced the state of Hungarian technical language and terminology at a particular period of time during the past hundred years. Over a long period of time, the most important part in establishing and disseminating adequate Hungarian terms was played by standards, dictionaries and the publishing of technical literature. Since this situation has dramatically changed by now, after presenting the current state of affairs, we make suggestions on handling terminological problems emerging in the course of technical communication, the instruction of technical language or the translation of technical literature.
\end{abstract}

Keywords: technical language, terminology, creating terms

\section{Introduction}

In the last two articles of this series, we presented the forming and initial development of Hungarian technical language and terminology from a linguistic point of view. In the third and also last article we will review the past nearly one hundred years based on linguistic approaches previously outlined. In this period we can observe several very different tendencies. While in the period between the two world wars we can see processes similar to the ones before, a lot of remarkable changes occurred after this period. Another change can also be observed from the 1990s onwards, the effects of which on technical language and terminology can still be felt.

\section{The period between the two world wars}

As in the previous years, it was again the self-organising association of engineers that was responsible for most for the development of Hungarian technical terminology. While special language terms had earlier been coined by different departmental organisations, in 1921, the Hungarian Industrial Standardisation Committee was set up, which was the first standardisation body that comprised all special fields. In 1933 it was followed by the Association of Hungarian Standardisation and the Hungarian Standardisation Institute Association [1] in 1941. These organisations actively participated in international standardisation processes, too. 
In 1923, for example, a report by the Hungarian Industrial Standardisation Committee appeared in the Bulletin of Hungarian Engineers and Architects informing the readers about being approached by their Swiss partner organisation to give their opinion on the Encyclopaedia of International Normalia planned to be compiled at a later time [2]. The fact that the ISA 37 'Terminology' committee, set up by the International Standards Association (ISA) held its first meeting in Budapest in 1936, [3] was internationally recognised.

The only significant dictionary of technical terms in this era was compiled by the mechanical engineer, Elemér Pávó in German-Hungarian language pairs, with the help of a mechanical engineer, Zénó Terplán. The dictionary was published in two volumes (German-Hungarian and Hungarian-German) in 1944, titled Modern Dictionary of Technical Terms.

\section{3 . The second half of the 20 th cen- tury}

After the Second World War, there were significant changes in the use of technical terminology. Previously, the written version of technical terminology was only used in scientific publications, standards, books on technology and instructional literature. The authors and readers of technical texts, whether created in the source language or translated, were solely professionals or students in a given field.

In the 1950s the mass production of technical goods began worldwide. These items need to be provided with technical specifications and user's manuals, and they were often translated into other languages, too. It meant that numerous texts were read, and in many cases created, by non-professionals.

From the beginning of the 1950s, three areas can be highlighted that have greatly contributed to unifying the usage of terminology in the field of professional commu- nication and the translation of professional literature. These areas are: standardisation, publishing of dictionaries and books on technical subjects.

\subsection{Standardisation}

The changes can first be observed in the area of standardisation. In 1948 standardisation was nationalised and at the same time usage of Hungarian standards was made compulsory [1]. Thus, any technical expert working in the field of research, education or industry had to know and use the standards that were valid at a particular point in time. Since the texts of standards were jointly created by experts working in the industry, or professors teaching and doing research at higher education institutions, the newly coined technical terms were based on a broad consensus. They used valid standards to publish excerpts from different publications in special fields, which proved to be very useful in higher education [4]. Students had the opportunity to learn about the most important standards and terms of their specialist fields during their studies. Standardisation at this time was financed by the state.

\subsection{Dictionaries}

In the 1950s there was significant progress in the area of publishing dictionaries. The publishing house of the Hungarian Academy of Science, founded in 1950, placed great emphasis on publishing dictionaries, among others bilingual and multilingual dictionaries for special purposes along with encyclopaedias in specialist fields. As a result, in 1953 the one-volume GermanHungarian and Hungarian-German Technical and Scientific Dictionary were published by Lóránt Katona.

The rapidly growing amount of technical terms due to the dramatic progress in technology and the need to handle terminology more effectively required the compilation of a new, two-volume dictionary that con- 
tained only technical terms. While working on this dictionary, one of the authors, János Klár, an electrical engineer, wrote Major issues of the forming and development of scientific-technical terminology in collaboration with the linguist, Miklós Kovalovszky. The book was published in 1955 by the Union of Technical and Natural science Associations. The preparatory works prove that in this case the compilation of the above-mentioned dictionary was both professionally and linguistically well founded.

The new dictionary appeared in 1959 in two volumes edited by electrical engineer János Klár, and mechanical engineer Ernő Nagy. The third edition, published in 1970 was supplemented by an appendix containing the most important technical terms having emerged since its first edition in new areas of technology, for example, information theory, control technology, operational research, etc. [5]. Subsequently, the dictionary had nine more unchanged editions.

It was also in 1959 that the first volume of Technical Encyclopaedia came out. The editor of the series was János Klár. The different volumes were compiled by the most distinguished specialists in their given field. The aim of these volumes was to summarize and, with the help of precise definitions, present the accepted and standardised terms of different specialist fields. When needed, new terms were even coined for the missing Hungarian equivalents.

\subsection{Books on technology}

In 1955 the Technological Publishing House was founded, which published school textbooks, books on science and technology, as well as educational literature for a wider audience. A lot of comprehensive handbooks and pocketbooks were published by the Technological Publishing House in the field of technology for various technical fields. These books were also very useful in the higher education of technical subjects. In order to provide high quality for the books to be published, the publishing house printed a guide for its authors and translators on two instances. In the guide published in 1982, the following can be read: The author has to take Hungarian standards into consideration. The manuscript may not contain anything that is in contrast with or divergent from the national standard. The standardised name of the given piece of machinery, tools, etc. must be used at all times along with its standardised denotation [6]. Due to their professionalism and efforts as well as their monopoly, the publications of the Technological Publishing House greatly contributed to the dissemination of standardised technical terms.

\section{From the 1990s until today}

While the previous decades could be characterised by continuous and deliberate standardisation, work with terminology and wide dissemination of standardised terms, the 1990s saw dramatic changes in all fields.

\subsection{Standardisation}

In 1995 the Hungarian Standards Institution was founded, whose number one priority was to prepare the accession to the European Union. Since this time conforming to standards has not been binding [1]. After the accession, European standards were continuously being introduced by the MSZT in English, with a Hungarian approval note. Although the official language of European standards (EN) is English, in many cases it can be felt that they have been 'adapted' from the German DIN standards. In these instances both technical content and the use of terms is appropriate. With newly compiled standards however, a lack of professional thoroughness and correct terminology is frequent. It can partly be caused by the fact that standards were subject to copyright protection, so commercial 
aspects often became more important than quality. Since August 2007 all European Union Standards are effective Hungarian standards, too. As MSZT is currently given only a minimum of state aid for activities relating to standardisation, it can only have the most important standards translated with adequate quality control [7]. In some areas of the industry we can see examples where industrial agents in different industrial sectors have the verified Hungarian translation of English language standards made through partnership and financial support. However, it affects only a very few areas of the industry. In other technological areas it is often the case that a new term does not have an approved equivalent in Hungarian. This, on the one hand, may partly hinder a professional dialogue in Hungarian; on the other hand, the lack of codified translations based on professional dialogue might have serious technical, economic and legal consequences [4].

Another problem related to standardisation is caused by the standardisation activity of foreign companies having subsidiaries in Hungary. Companies holding internationally strong economic positions tend to work out so-called 'de facto' standards for their own business (e.g. industrial, sectoral and corporate standards). In certain cases, these may significantly differ from internationally applicable standards [8]. Enterprises use company standards in order to consciously and deliberately distance themselves from the competition. We usually find firmspecific terminology in these standards. Accordingly, processes previously going towards unified standardisation have, in many industrial sectors, not only slowed down but have moved in the opposite direction: in the area of standardisation and coining terms, the goal for companies is to distance themselves from each other. Even from these sectoral and company standards, not many that are verified by experts get to be translated into Hungarian, so the termi- nology used does not have Hungarian equivalents.

\subsection{Dictionaries}

After the unabridged dictionary with 12 reprints by János Klár and Ernő Nagy, in 2007, the German-Hungarian Dictionary of technical and scientific terms by Ákos Tóth was published by Akadémiai Kiadó (Academy Publishing House). It was a paperbased dictionary supplemented by a CD. According to the information provided by the publisher, the body of words was built on that of previous bilingual and German monolingual dictionaries which were supplemented by the editor's own compilation. Presently, this dictionary can only be used online, with a subscription, and the body of words is being periodically developed. The publisher has no plans for compiling a Hungarian-German volume.

In the last few years, online dictionaries of special terminology have started to appear in great numbers. These fall into two categories: those compiled by publishing houses, continually developed and verified, with a subscription. The other category covers dictionaries compiled and extended by enthusiastic amateurs. General language dictionaries containing special terminology belong here along with dictionaries of special terminology whose body of words is usually restricted to a special field. The quality of these dictionaries is not reliable at times, although there has been some improvement during the past one or two years. Since online dictionaries can easily be accessed and are often free, they are used by a lot of people.

Also recently, multilingual terminological databases have been developed with a conceptual structure. These can be used in many ways. They are primarily for professional translators and are not available to outsiders. With the help of stored patterns, these databases are also capable of finding a target language equivalent for the meaning 
of the term looking for within the given context. The previously mentioned terms used by a given company can also be aligned to a concept by providing the company source. In German linguistic regions, the body of two or multilingual dictionaries is compiled and updated by data taken from such terminological databases.

\subsection{Books on technology}

Towards the end of the 20th century more and more publishers began to consider publishing books with a technical subject. These newly founded publishers did not always have the appropriate professional background for providing the necessary professional quality. The books often translated by non-experts were not proofread by a language editor or expert of the field, so the usage of terms was not always adequate. The publishing of manuals and pocketbooks that could be used in higher education in technology has also practically ceased, so currently, only a couple of professions have a 'summarising' literature that is updated.

\section{The current situation in the us- age of Hungarian language technical terms}

Since, in the past nearly two decades, almost all factors that previously supported a unified and standardised usage of technical terms have weakened; we face major problems in a lot of areas.

Instruction of special terminology and its translation is very difficult without students being able to use adequate dictionaries or terminological databases of a specialist field. Presently, students in higher education do not have access either to standards translated into Hungarian, or excerpts made from these. The usage of terminology in Hungarian references used by students during their studies is not unified either. The usage of special terms read by students on the internet in different kinds of the literature in a given field is often vague.

As for companies and professional translation agencies, in the case of translation tasks translators build up a companyspecific terminological database with the help of professionals in the field of technology. These databases can be well built, but inaccessible for external users. It may also pose a problem that company-specific databases cannot always be used with texts to be translated for another company within the same sector of the industry.

The lack of adequate Hungarian terms can also make professional communication between experts difficult. In these instances, especially in case of oral communication, the conversing parties tend to insert the well known foreign language term into a Hungarian sentence. This, however, means that after a time the Hungarian language of technology won't be able to cope with the fast technological development.

We may consider the more or less standardised tuning in the written and oral language of technology as a kind of international terminology, for example in welding and similar processes, and in cases of lack of material continuity. The usage of tuning makes professional communication more concise and unequivocal.

\section{Conclusions}

If we would like to do something about the currently bad situation of Hungarian technical terminology, then first we have to make big progress in the area of standardisation and dictionaries of technical terms.

It would be necessary to translate more and more standards into Hungarian. Translations would need to be done by experts in the given field, and translations would have to be proofread in all cases. As a result, a standardised terminology of different fields would come into being. The Magyar Mérnöki Kamara (Hungarian Chamber of 
Engineers) should play an important role in this work.

The standardised terms found in newly translated standards could be a starting point for the compilation of a terminological database with the help of which an online dictionary of technical terms could be edited - one that could constantly be improved and updated. This would be of great help in all fields of instruction of technological terms, especially in that of the language of a specialist field and in the training of translators.

Until the time these aids are available in education, we still need to support the work of students in other ways. One possible method for gaining the necessary terms is to use parallel texts. These are texts, originally written in Hungarian that uses Hungarian terminology in the given field. Students should always be instructed to use texts only from 'authentic' sources, for example, books on a specialist field, notes published by the university or slides of lectures.

Another method in German - Hungarian language pairs would be to acquaint students with the possibilities of the interpretation of complex German technical terms, or the traditions of coining terms in Hungarian. However, achieving results with this method requires a longer period of time [9].

\section{References}

[1] Pónyai Gy.: Szabványosítás és terminológia. Journal of Hungarian Terminology (Magyar Terminológia) 3/1. (2010) 3-7. https://doi.org/10.1556/MaTerm.3.2010.1.2

[2] Magyar Mérnök- és Építész-Egylet Közlönye, 57/1-2. (1923) 8.

http://dokutar.omikk.bme.hu/collections/mee/ fajlok/1923-8-8.pdf

[3] Magyar Mérnök- és Építész-Egylet Közlönye, 71/51-52. (1937) 364-376.

http://dokutar.omikk.bme.hu/collections/mee/ fajlok/1937-364-376.pdf

[4] Zabóné Varga I.: A müszaki terület terminológia-politikája. In: Nyelvi mítoszok, ideologiák, nyelvpolitika és emberi jogok Közép-Európában elméletben és gyakorlatban. A 16. Élőnyelvi Konferencia anyagai. (eds.: Híres-László K., Karmacsi Z., Márku A.) Tinta Könyvkiadó, Budapest, 2011, 473-475.

[5] Magyar-német müszaki szótár. (eds. Nagy E., Klár J.) 6,edition, Akadémiai Kiadó, Budapest, 1992.

[6] Horváth J, Makk A. Tartsay V.: Hogyan irjunk, szerkesszünk müszaki könyvet?, Müszaki Könyvkiadó, Budapest, 1982, 57.

[7] Fóris Á.: Hat terminológia lecke, Lexikográfia Kiadó, Pécs, 2005. 24.

[8] Galinski C.,Weissinger R.: Terminology standardization and translation standards. Magyar Terminológia, 3/1. (2010) 11. https://doi.org/10.1556/MaTerm.3.2010.1.3

[9] Zabóné Varga I.: Müszaki szövegek forditásának terminológiai problémái német-magyar nyelvpárban jármüipari szövegek alapján. Disszertáció, Budapest, 2015. 101-108. https://doi.org/10.15476/ELTE.2015.084 